\title{
Evaluating the Effects of Nearshore Development on Wisconsin Lakes
}

\section{Why are the effects of development a concern?}

The Wisconsin Department of Natural Resources (WDNR) has estimated that the amount of development along Wisconsin lakes in the last 30 years is greater than that which occurred in the previous 100 years, and that as much as 90 percent of the private land adjacent to lakes and rivers will be developed by the year 2025 (WDNR, written commun., 2005). The rapid rate of shoreline development in Wisconsin has raised concerns that future development may impair water quality in lakes. Development can increase runoff volume as well as sediment and pollutant loads. One nutrient associated with runoff is phosphorus, which is often responsible for increased algae in lakes (Robertson and others, 2005). For example, at one Wisconsin lake, runoff accounted for about 4 percent of the water flowing into the lake but 51 percent of the total phosphorus input (Garn, 2002). Development may also reduce water that sustains the ground-water system (ground-water "recharge") and may adversely affect springs that feed a lake (the cold water you feel while wading near the shore). Surface runoff, reduced ground-water recharge, and lake impact are interrelated, and movement of water between these systems varies seasonally or even daily depending on changing conditions. Mitigating adverse effects after development has occurred along a lake can be expensive and difficult. Overlying these concerns are issues such as stewardship of the resource, the rights of the public, and landowners' rights—-both for those developing their land and those whose land is affected by this development. When there are contradictory goals, a scientific basis for assessing effects of development and effectiveness of mitigation measures helps ensure fair and constructive decision-making. To better assess the effects of development on lakes, the U.S.

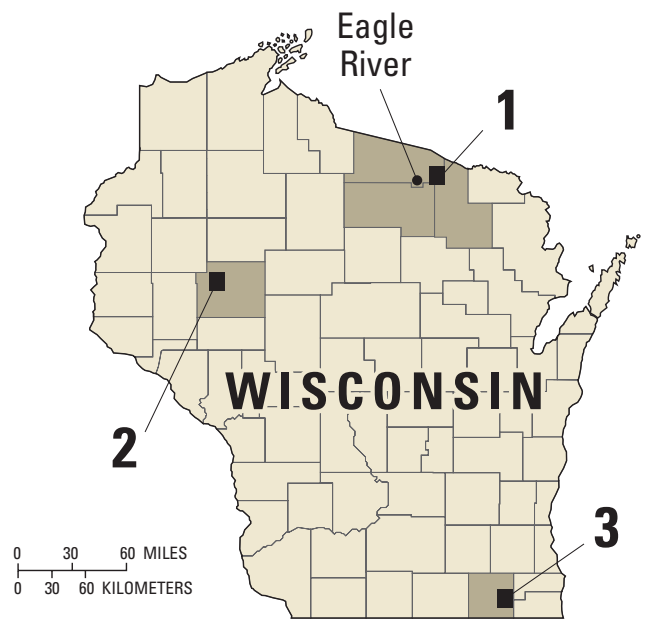

Figure 1. Location of data-collection sites: 1-Vilas, Forest, and Oneida Counties (Graczyk and others, 2003); 2-Chippewa County (Graczyk and Greb, 2006); and 3-Walworth County (Graczyk and Greb, 2006).

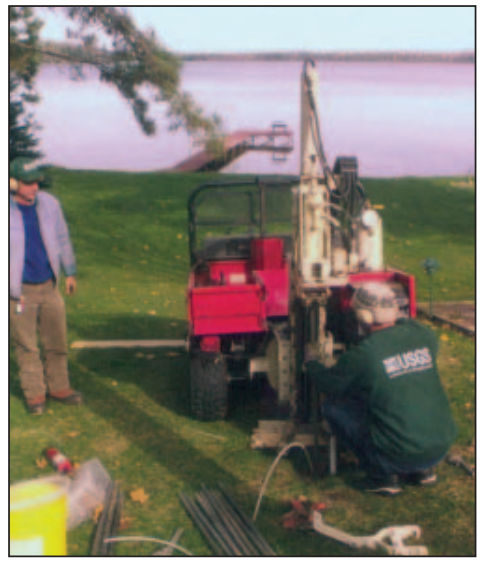

\author{
Wells were installed for \\ ground-water sampling using \\ a soil probe mounted on a \\ four-wheel drive all-terrain \\ vehicle. This allowed the \\ wells to be installed with \\ minimum disturbance in the \\ lawn and wooded sites, and \\ ensured shallow and deep \\ ground water was included in \\ the sampling.
}

Geological Survey and the WDNR have conducted several studies on how nearshore development affects flows of water and nutrients to lakes. This Fact Sheet discusses the results of these studies.

\section{How were the studies designed?}

In the initial work by Graczyk and others (2003), a paired sampling approach was used, whereby adjacent developed (lawn) and undeveloped (woods) areas were monitored on four lakes in north-central Wisconsin from 1999-2001 (fig. 1). The developed/ undeveloped pairs were characterized with respect to their ability to infiltrate water and their loading of nutrients to the lakes. The study included measurements of: rainfall; surface runoff and water quality; ground-water flow and water quality; ground-water levels; soil temperature; and soil-moisture data. Water-quality sampling focused primarily on the nutrients nitrogen and phosphorus.

Based on results from the initial study, two lakes, one in Walworth County, Wisconsin, and one in Chippewa County, Wisconsin (fig. 1), were later monitored to identify how water moved through the shallow soil and how vegetated buffers influenced this flow (Graczyk and Greb, 2006). During this study, vertical shallow soil-moisture profiles were measured along transects that included an upslope lawn, an intermediary vegetated buffer, and a downslope wooded site. The measurements were collected under natural rainfall conditions and controlled water additions. The datasets collected during this study provided insight into the small-scale processes operating at the developed and undeveloped sites.

\section{What the studies found}

\section{Identification of changes in water flows and soil conditions at the small catchment scale}

The surface-runoff volumes from the wooded catchments were quite low ( 0 to 0.5 percent of the precipitation falling on the catchment). At one undeveloped site, no runoff occurred during the entire study period (October 1999-September 2001). Surface runoff from 
the developed lawn catchments, however, was generally 10 or more times higher than that from the wooded site runoff (fig. 2). Average lawn runoff varied from a low of 0.2 percent to a high of 6 percent of precipitation, with the highest value measured on the least-permeable soils. Lawn sites also had more runoff events during the study (average of 18.5 per site) than the companion wooded sites (average of 11.2 per site). The low runoff observed in the wooded catchments was likely a result of a number of factors: (1) the tree canopy intercepted a portion of the precipitation, which reduced the intensity and enhanced evaporation of the rainfall; (2) the relatively uncompacted organic-matter layer at the ground surface reduced rainfall impact and absorbed rainfall; and (3) increased permeability in the upper soil due to bioturbation (for example, worm holes) may have allowed most of the precipitation to infiltrate.

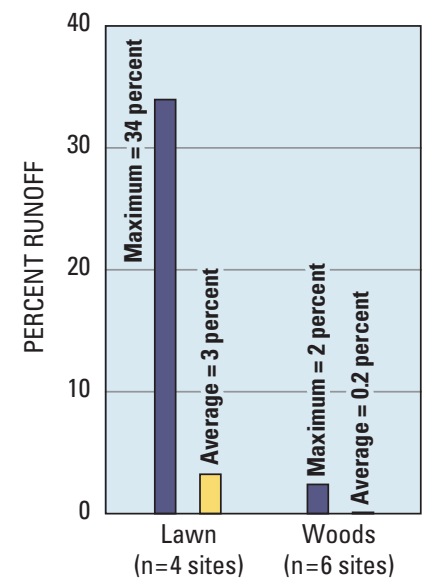

Figure 2. Percent of precipitation converted to runoff for events measured during the study, 0 ctober 1999-September 2001. The amount of runoff generated from a given rain volume was significantly higher at the lawn sites than at the wooded sites ( $p<0.05$ )(Graczyk and others, 2003).

Conditions measured in soils at the sites also suggest differences in factors that may affect infiltration. During the growing season, soils in the lawns are warmer than soils in the woods because of reduced shading and increased solar radiation. Worms and other burrowing animals are likely to be more frequently found in the cooler, shaded areas rather than in the warmer lawn areas. Soils in the wooded sites were commonly moist. At the lawn sites, however, soil moisture depended on position in the catchment. Soil moisture measured under the lawn on a slope was drier than that measured at the adjacent wooded site. Soil moisture measured under a flat lawn site downhill from a lawn slope was higher than that measured in the adjacent wooded site on a slope, reflecting the addition of water generated in the lawn upslope. These results suggest that the effects of nearshore development depend on the type of landscape next to the lake. Lawns on slopes that end at the lake can be expected to add additional runoff directly to the lake. Lawns that end in flat areas or buffers, on the other hand, may not result in increased runoff to the lake because these areas often have a greater ability to infiltrate runoff.

\section{Identification of changes in nutrient flows at the small catchment scale}

For equal-sized areas, the amount of nutrients exported by surface-water runoff was greater from the developed lawn catchments than that from the undeveloped woods at all sites for all nutrients studied (fig. 3). This increase in nutrient loading to the lake held true for all nutrients measured. For nitrate plus nitrite, Kjeldahl nitrogen, and total phosphorus, the developed lawn loading was 10 to 100 times more than the undeveloped woods loading. Higher loads were not a result of higher nutrient concentrations in the lawn runoff, however. Instead, the lawn sites had higher runoff frequency and volume, which resulted in more nutrient-carrying water leaving the catchment.

The ground-water system also carried appreciable concentrations of nutrients to the lakes. Ground water under the lawn areas had concentrations of nitrate and total phosphorus 3 to 4 times higher than concentrations measured in ground water beneath the wooded catchments. The highest concentrations of these nutrients were measured in the lawn site in a flat area downslope from a lawn slope. This finding suggests that higher rates of lawn runoff infiltration such as those noted above can result in enhanced nutrient loading to the ground-water system, and subsequently to the lake, even if the runoff itself does not reach the lake. Elevated nutrient concentrations were also noted in deeper ground water beneath both types of catchments, reflecting land use in areas more distant from the lake. Ground-water modeling in Graczyk and others (2003) also demonstrated the importance of these distant areas for supplying ground water to the lake (fig. 4). Thus, a lake can be affected by land use in somewhat distant areas even if they do not contribute surface runoff to the lake. Moreover, because it takes time for ground water to travel from distant areas to the lake, there is a lag between the time land-use changes occur and when these changes are observed in ground water flowing into the lakes. Accurate long-term estimates of the effects of changing land use would need to account for this lag.

\section{Evaluation of water infiltration and the importance of buffers}

Additional insight into how runoff and buffers interact was gained using the soil-moisture profile transects instrumented in 2003-2005 (Graczyk and Greb, 2006). In a controlled water-addition experiment, a downspout was simulated by adding water as a point discharge to a lawn and tracking soil moisture downslope. The volume of water added to the lawn was approximately equivalent to a 2-inch rain falling over a 6-hour period on a 2,200 square-foot impervious area, which might include roofs of houses and garages, driveways, and patios. The added water moved horizontally as well as vertically, showing up 25 feet downslope in less than 3 hours at the lawn/woods buffer contact at depths greater than 8 inches (fig. $5)$. No indication of the water addition, however, was observed at

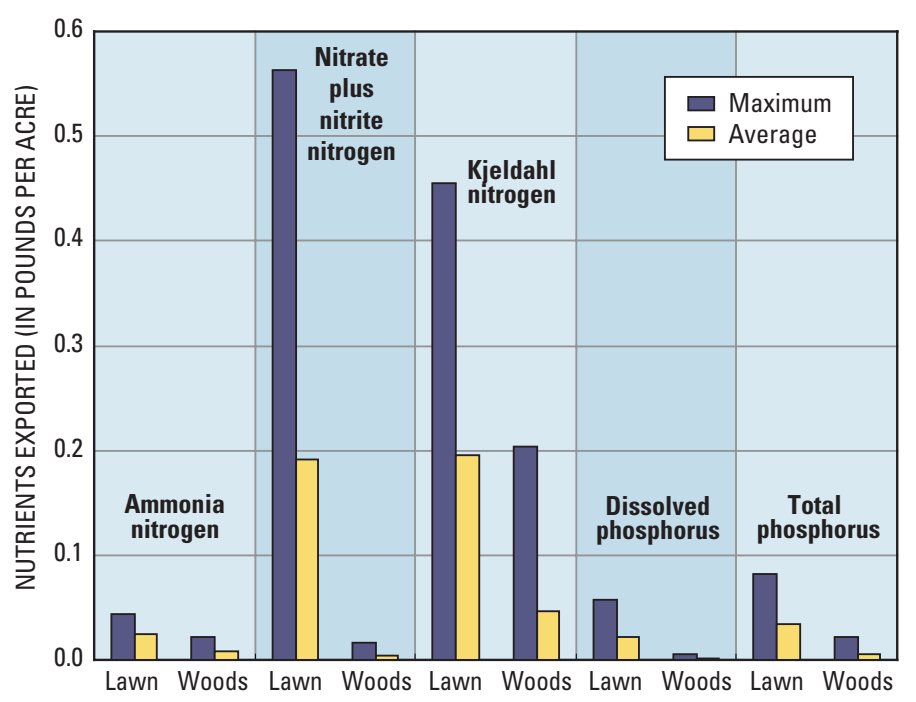

Figure 3. Median amount of nutrients exported normalized by area for events measured during 1999-2001. Results from the wooded sites were significantly lower for all nutrients $(p<0.05)$ (Graczyk and others, 2003). 


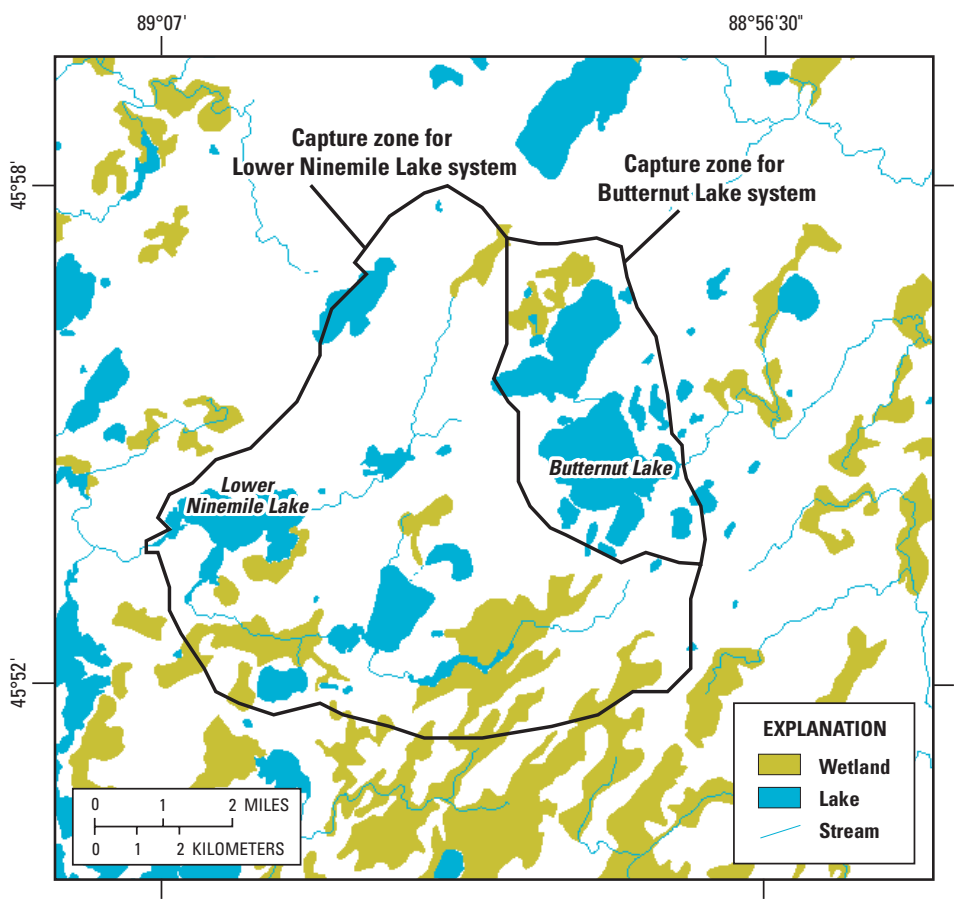

Figure 4. Model simulated ground-water capture zones for two lakes demonstrate that lakes receive water from distant areas as well as nearshore areas. A lake's capture zone also includes areas that contribute water to the streams that flow into a lake. Given sufficient time, lakes are affected by land-use change that occurs anywhere within their capture zone (modified from Graczyk and others, 2003). the next measurement point an additional $25 \mathrm{ft}$ downslope (fig. 5), reflecting the smaller water volume as well as the higher infiltration capacity within the buffer. The flat portions of the curves in figure 5 indicate times when the soil was saturated and the ability to transmit water was greatest. Although the lawn site had the maximum ability to infiltrate at all depths during the test (as indicated by the flat slopes in the soil moisture curves in figure 5), the water added from the simulated impervious area was more than could be infiltrated, resulting in horizontal flow within the soil downslope toward the lake. Larger water volumes, such as those that would result from larger impervious areas, would increase this flow. In contrast, reducing the amount of impervious area that contributes water (equivalent to reducing the amount of water added in the experiment) would decrease the amount of horizontal flow toward the lake. The fact that runoff traveled more than 25 feet under the lawn (fig. 5), but then was infiltrated before it traveled the next 25 feet in the buffer, underscores the importance of an appropriate land-use setback from a lake or stream. Larger setbacks with native vegetation buffers would increase the likelihood that high-intensity rainfalls would be infiltrated before entering a lake.

\section{Implications for lakes}

The results of the studies demonstrate that the conversion of undeveloped wooded areas into lawns can significantly affect both flow of water and nutrients to lakes. Large increases in lawn nutrient contributions were due to increased runoff volumes; therefore, reducing runoff to a lake is critical for minimizing adverse effects. Reducing the amount of impervious area increases the amount of land available for infiltration and reduces the water added to local areas within a site, which in turn helps ensure that the soil's ability to infiltrate water will not be exceeded. Appropriate setback

\section{Study methods and site description}

A paired sampling approach was used in this study. For the 1999-2001 monitoring, areas of adjacent developed and undeveloped areas were simultaneously monitored on four lakes in north-central Wisconsin (Graczyk and others, 2003). The developed catchments consisted mainly of lawns; the undeveloped catchments consisted of varying mixtures of mature and immature deciduous and coniferous woods. Precipitation, surface runoff and water quality, ground-water flow and water quality, ground-water levels, soil temperature, and soil-moisture data were collected from the small ( 85 to $\left.1,080 \mathrm{ft}^{2}\right)$ catchments. To determine variability within sites, multiple undeveloped and developed subcatchments were monitored within each site.

The quantity and quality of surface-water runoff were sampled using below-ground sample bottles. Runoff was directed into the bottles using 10 -ft-long barriers installed on the ground surface using 0.5 -in PVC pipe with slots or plastic lawn edging driven into the ground (see diagram at right). The barrier was placed perpendicular to the slope, so that surface runoff was intercepted and drained into collector bottles that were buried nearby. The samplers were checked weekly by a local observer and after rain and snowmelt events. Samples were analyzed at the Wisconsin State Laboratory of Hygiene; water volumes collected from each storm were coupled with the corresponding concentration data to determine areal loads and yields.

In the 2003-2005 sampling, a lawn, vegetated buffer, and wooded site were instrumented with a vertical profile of sensors that measured soil moisture. The soil-moisture probes were placed in a line that traversed a lawn to a wooded buffer to determine both vertical and horizontal movement of water. At each probe, soil moisture was monitored $10 \mathrm{~cm}, 20 \mathrm{~cm}, 30 \mathrm{~cm}, 40 \mathrm{~cm}$, and $50 \mathrm{~cm}$ below the land surface. In addition, a tipping-bucket raingage was installed at each site to determine rainfall. Measurements were collected at 1-hour intervals and included time periods that encompassed natural rain events. A controlled experiment was also performed during which known volumes of water were added to lawn and wooded areas.
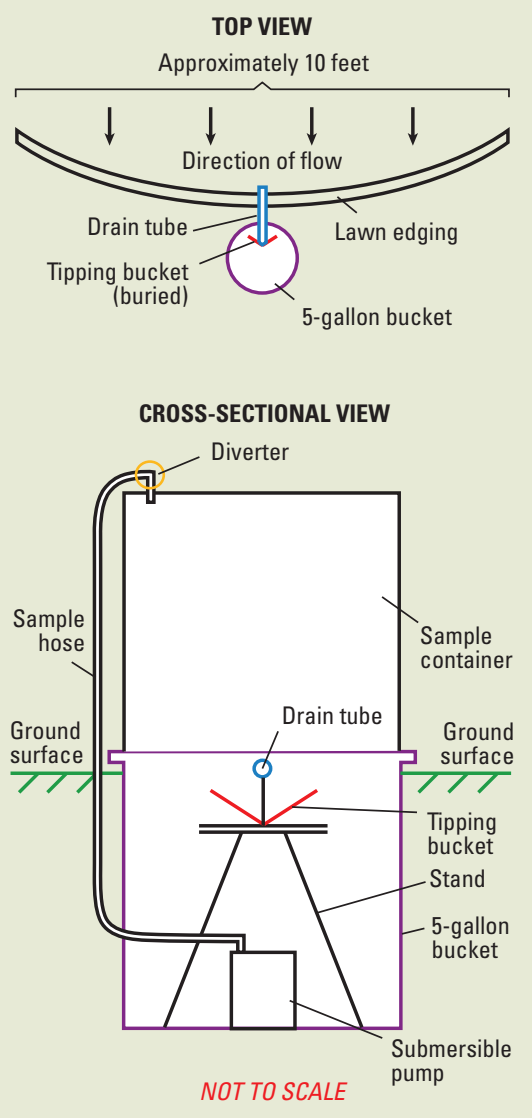


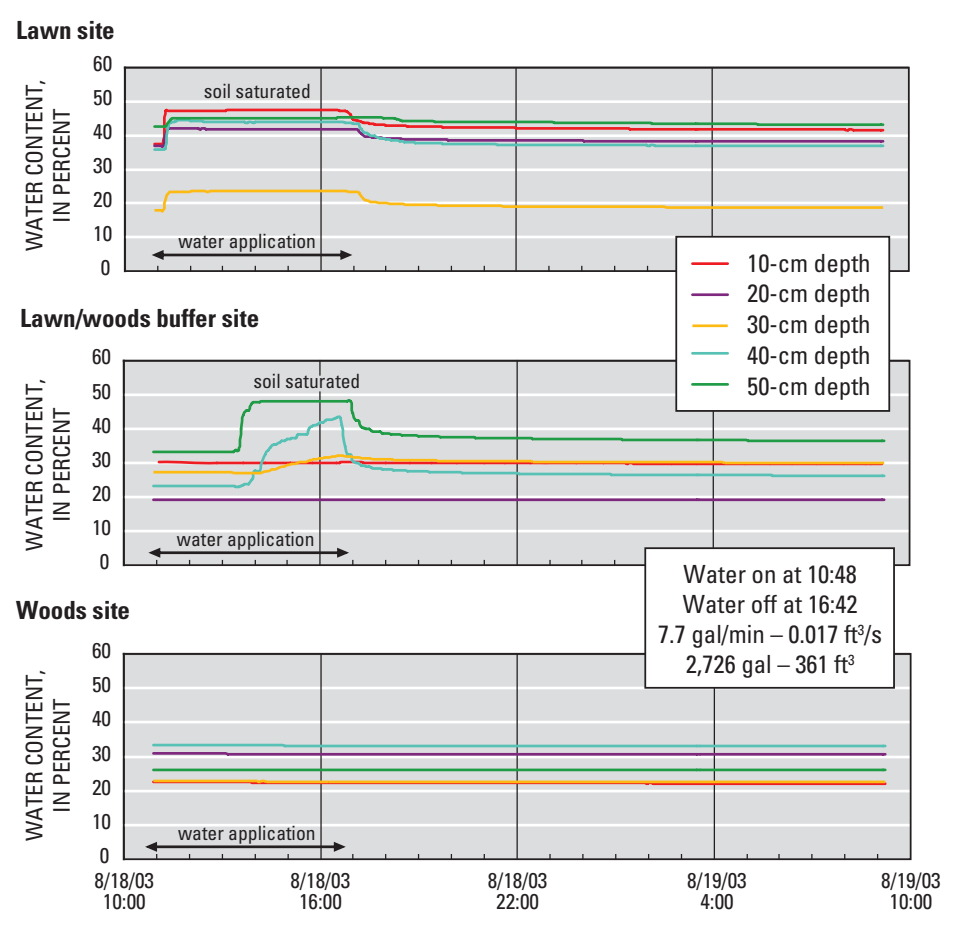

Figure 5. Soil-moisture profiles for the Walworth County site for a water-addition experiment along a transect that included an upslope lawn site, an intermediary buffer site, and a downslope wood site (Graczyk and Greb, 2006).

distances and buffers between impervious areas and lawns and lakes are important because they enhance a site's ability to absorb water before it is conveyed to a lake. Areas with slopes draining directly into a lake are expected to have the highest runoff amounts and associated nutrient loading. Lawns where slopes do not terminate at a lake, and areas with intervening flat or buffer zones between the lawn and a lake are more apt to infiltrate runoff, thereby reducing potential adverse effects on a lake.

Ground water was also affected by the degree of development. Both nearshore areas and distant areas supplied ground water and ground-water-transported nutrients to the lakes. Thus, lake protection should have a watershed focus in addition to a focus on nearshore areas. Moreover, understanding the effects of distant areas may be important for lake protection in the future as off-lake development increases and developable nearshore land becomes scarce.

\section{What landowners are doing to limit the effects of development on lakes:}

- Maintaining a natural landscape with native vegetation

- Leaving or maintaining buffer strips (WDNR currently (2006) recommends at least 35 feet)

- Not installing lawns on slopes that drain to lakes

- Not adding fertilizer to lakeshore lawns

- Limiting the amount of impervious areas on their site such as sidewalks, driveways, and rooftops

- Reducing erosion

- Enhancing infiltration of runoff from rooftops, driveways, and other impervious areas

- Not removing woody vegetation from nearshore areas

- Installing rain gardens to enhance runoff infiltration
It should be noted that the areal nutrient loading rates in lawn and woods sites calculated in this work were generally less than those found in the previous studies. The difference is likely due to generally larger catchment areas investigated in the other studies, which incorporated added runoff volumes from impervious source areas, such as driveways and rooftops (Steuer and Hunt, 2001). In addition, development often results in compacted and disturbed soils (Owens and others, 2000) that can reduce infiltration of runoff. These factors would augment the effects of the lawn land use evaluated here.

Finally, the focus of this work was on comparisons of individual catchments that feed lakes; the cumulative effect of multiple developments on a lake was not studied. However, the resiliency of a lake can change with time as additional development occurs (Carpenter, 2003), much like a boxer withstanding a punch in the first round only to be knocked out by a similar punch in a later round. How a lake has responded in the past to land-use change may not reflect how it will change in the future (Hunt, 2003). This complexity underscores the need for sound watershed-scale understanding of systems rather than only depending on the approaches of the past. With such an understanding, decision-makers will be better able to protect water resources for generations to come.

\section{References}

Carpenter, S.R., 2003, Regime shifts in lake ecosystems: pattern and variation, in Kinne, O., ed., Excellence in ecology, Book 15: International Ecology Institute, Oldendorf/Luhe, Germany, 199 p.

Garn, H.S., 2002, Effects of lawn fertilizer on nutrient concentration in runoff from lakeshore lawns, Lauderdale Lakes, Wisconsin: U.S. Geological Survey Water-Resources Investigations Report 02-4130, 6 p.

Graczyk, D.G., and Greb, S. R., 2006, Soil Data at Sites near Geneva Lake, Lake Geneva, Wisconsin, and Long Lake, near New Auburn, Wisconsin: U.S. Geological Survey Open-File Report 2006-1191, 10 p., 2 digitial appendixes, accessed July 20, 2006 at http://pubs.usgs.gov/of/2006/1191/

Graczyk, D.G., Hunt, R.J., Greb, S.R., Buchwald, C.A. and Krohelski, J.T., 2003, Hydrology, nutrient concentrations, and nutrient yields in nearshore areas of four lakes in northern Wisconsin, 1999-2001: U.S. Geological Survey Water-Resources Investigations Report 03-4144, 64 p.

Hunt, R.J., 2003, A water science primer: Wisconsin Academy of Sciences, Arts and Letters Transactions, v. 90, p. 11-21.

Owens, D.O., Jopke, P., Hall, D.W., Balousek, J., and Roa, A., 2000, Soil erosion from two small construction sites, Dane County, Wisconsin: U.S. Geological Survey Fact Sheet FS-109-00, 4 p.

Robertson, D.M., Rose, W.J., and Saad, D.A., 2005, Water quality, hydrology, and phosphorus loading to Little St. Germain Lake, Wisconsin, with special emphasis on the effects of winter aeration and ground-water inputs: U.S. Geological Survey Scientific Investigations Report 2005-5071, 36 p.

Steuer, J.J., and Hunt, R.J., 2001, Use of a watershed-modeling approach to assess hydrologic effects of urbanization, North Fork Pheasant Branch Basin near Middleton, Wisconsin: USGS Water-Resources Investigations Report 01-4113, $49 \mathrm{p}$.

\section{Acknowledgments}

The authors acknowledge the assistance of the land owners who graciously allowed us to install equipment and monitor surface- and ground-water flow on their properties. We are also grateful for the assistance of Sandra S. Gillum in initially locating the sites and assisting with data collection and Theodore W. Peters (Director, Geneva Lake Environmental Agency, Lake Geneva, Wis.) and Patrick "Buzz" Sorge (WDNR) for locating sites in Walworth and Chippewa Counties, respectively.

Authors: Randall J. Hunt, Steven R. Greb (WDNR), and David J. Graczyk 